\title{
Biological Evaluation of PLDLA Polymer Synthesized as Construct on Bone Tissue Engineering Application
}

\author{
Bruna Antunes Mása, Diego Coutinho de Luna Freire ${ }^{b}$, Silvia Mara de Melo Cattani ${ }^{b}$, \\ Adriana Cristina Motta ${ }^{b *}$, Maria Lourdes Peris Barbo $^{b}$, Eliana Aparecida de Rezende Duek ${ }^{a, b}$ \\ ${ }^{a}$ State University of Campinas - UNICAMP, Rua Mendeleyev 200, CEP 13083-970, Campinas, SP, \\ Brazil. \\ ${ }^{b}$ Pontifical Catholic University of São Paulo - PUC-SP, Rua Joubert Wey 290, \\ CEP 18030-070, Sorocaba, SP, Brazil.
}

Received: September 16, 2015; Revised: November 29, 2015; Accepted: December 16, 2015

\begin{abstract}
In bone tissue engineering, cell-scaffold constructs are used to stimulate complete, functional tissue replacement that does not occur naturally in critical-size defects. In this report, we describe the application potential of poly (L-co-D,L lactic acid)-PLDLA 70/30, synthesized in house as constructs loaded with osteoblast-like cells on bone tissue engineering. In vitro biological results show that the porogen leached PLDLA scaffolds are cytocompatible with osteoblast cells, able to stimulate significant cells growth during the first 14 days of culture, during which the morphology and cell behavior of osteoblasts cultured on the scaffolds were monitored by scanning electron microscopy (SEM). In vivo, PLDLA constructs were implanted in $5 \mathrm{~mm}$ bilateral critical-size defects created in rat-calvariae and then evaluated histologically 8 and 12 weeks after implantation. The histological results showed that PLDLA constructs supported the growth of new tissue, with a degradation rate close to that of native bone formation and decrease of inflammatory response over time of implantation. These data provide evidences that the synthesized PLDLA polymer has application potential as construct for bone tissue engineering.
\end{abstract}

Keywords: Bone Tissue Engineering, Constructs, Implants, Osteoblast-like Cells, PLDLA.

\section{Introduction}

There are multiple reasons for developing new alternatives in the field of bone tissue engineering, including the need for better tissue replacement materials based on bioreabsorbable polymers that can be used as cell system scaffolds (constructs).

An ideal scaffold must have good biocompatibility to ensure cell survival and minimal immune response after implantation. In addition the scaffolds should have certain general requirements such as: biodegradability, bioactivity, good physical and mechanical strengths, low immunogenicity , ability to support vascularity and adequate pore size $e^{1,2}$. In vivo, these materials must provide mechanical support and a suitable biological environment for tissue formation, while their degradation must closely accompany tissue growth ${ }^{3,4}$.

Poly( $\alpha$-hydroxyacids) are aliphatic, bioreabsorbable polyesters that have been widely used in medical products such as sutures, bone screws, tissue engineering scaffolds and drug delivery systems. The advantages of this class of materials include their biocompatibility, biodegradability, ease of processing and possibility of modulating their mechanical properties ${ }^{5,6}$.

We have reported the synthesis and development of a number of bioreabsorbable polylactide-based polymers obtained by ring-opening polymerization of lactide and glycolide monomers ${ }^{7-10}$. Their potential use as biomedical

*e-mail: motta.adrianam@gmail.com devices and their biocompatibility with skin, bone, cartilage and neuronal tissue also have been explored ${ }^{11-15}$.

Among the polymers synthesized by the group, we highlight the amorphous copolymer poly(L-co-D,L lactide)-PLDLA which has molecular weight range of $10^{5} \mathrm{~g} / \mathrm{mol}$ and glass transition temperature of $55-60{ }^{\circ} \mathrm{C}^{8,16}$. The interest in using this polymer as biomedical devices in bone tissue engineering resides in the fact that its degradation rate can vary from 12 to 30 weeks depending on molecular weight, design and thickness of device and also, it does not generate crystalline fragments that induce tissue acute inflammatory response. Besides, it presents suitable mechanical properties and stability during degradation. PLDLA membrane has a tensile strength of about 47.5 MPa and Young's modulus of $197 \mathrm{MPa}$ whereas PLDLA plates can reach modulus of $2.0 \mathrm{GPa}^{17,18}$. These different mechanical properties call attention to the wide range of PLDLA applications in bone tissue, which has mechanical properties that can vary from $100 \mathrm{kPa}$ (pre calcified bone) to modulus of $20 \mathrm{GPa}$ (rigid compact bone) $)^{19}$.

In order to give continuity to the process of characterization of PLDLA polymer this work aimed to perform an in vitro and in vivo preliminary study of PLDLA scaffolds loaded with osteoblast-like cells used as constructs for bone regeneration in bilateral calvarial defects created in Wistar rats. 


\section{Materials and methods}

\section{Preparation of PLDLA scaffolds}

PLDLA 70/30 $(\mathrm{Mw}=180,000 \mathrm{~g} / \mathrm{mol}$, determined by GPC technique) was synthesized by ring-opening copolymerization of L-lactide and D,L lactide monomers, using tin (II) octoate as the catalyst, essentially as described by Motta, Duek ${ }^{8}$. PLDLA scaffolds were obtained by the porogen-leaching method. After complete PLDLA dissolution in chloroform $(10 \% \mathrm{w} / \mathrm{v}), 70 \%$ (w/v) sucrose (Synth) was added, with the pore size being controlled granulometrically to $250-500 \mu \mathrm{m}$. The solution was poured into a silicon cylindrical mold $5 \mathrm{~mm}$ in diameter and kept in this recipient until the complete evaporation of solvent. Cylindrical samples $(5 \times 5 \mathrm{~mm})$ were then punched out of the molds and placed in a $1 \%$ poly(vinyl alcohol), PVA, solution to remove the sucrose particles. For the experiments, PLDLA scaffolds were cutted at dimensions of $5 \mathrm{~mm}$ in diameter and $3 \mathrm{~mm}$ in thickness. The PLDLA scaffolds were disinfected in $70 \%$ ethanol for $30 \mathrm{~min}$ and exposed to UV light for $30 \mathrm{~min}$ on each side.

\section{In vitro experiments Cell culture}

Osteoblasts were obtained from explants of calvarial from three Wistar rats as previously described ${ }^{20,21}$. Briefly, the skin, soft connective tissues and periosteum were removed and then, calvaria were dissected from 15 day old of three Wistar rats. In a laminar flow, the calvaria were cut into small pieces and distributed in T25 tissue culture dishes in which they were cultured in a $5 \% \mathrm{CO}_{2}$ atmosphere at $37^{\circ} \mathrm{C}$ until confluence. Osteoblasts were cultured in Dulbecco's modified essential medium (DMEM) supplemented with $10 \%(\mathrm{v} / \mathrm{v})$ heat-inactivated fetal bovine serum (FBS), gentamicin $(50 \mu \mathrm{g} / \mathrm{mL})$, amphotericin B $(5 \mu \mathrm{g} / \mathrm{mL})$, ascorbic acid $(50 \mu \mathrm{g} / \mathrm{mL})$ and $10 \mathrm{mM} \beta$-glycerophosphate. The cells were then harvested using trypsin/EDTA and seeded onto 96-well culture plates containing the polymeric scaffolds of interest.

\section{Cell viability}

The cytotoxicity of the scaffolds was assessed by the MTT colorimetric assay in which MTT reagent (3-[4,5-dimetylthiazol2-yl]-2,5-diphe-nyltetrazolium bromide) was reduced to a purple formazan product by the mitochondria of living cells. Cells cultured on tissue-culture polystyrene plates (TCPS) were used as a positive control and the negative control consisted of cells cultured on tissue-culture polystyrene plates containing $1 \%$ phenol (TCPS+ phenol 1\%). Cells $\left(2 \times 10^{5}\right.$ cells $/ \mathrm{mL}$ in $200 \mu \mathrm{L}$ of DMEM supplemented with $10 \%$ FBS) were seeded in wells containing the scaffolds and incubated for $2 \mathrm{~h}$ and $24 \mathrm{~h}$. The culture medium was removed and the wells then washed twice with $0.1 \mathrm{M} \mathrm{PBS}, \mathrm{pH} 7.4$, at $37^{\circ} \mathrm{C}$ followed by the addition of $180 \mu \mathrm{L}$ of DMEM and MTT assay mixture $(20 \mu \mathrm{L} /$ well, containing $5 \mathrm{mg}$ of MTT reagent $/ \mathrm{mL}$ ). After incubation for $4 \mathrm{~h}$ at $37^{\circ} \mathrm{C}$, the cells were lysed by adding $200 \mu \mathrm{L}$ of dimethylsulphoxide (DMSO). Subsequently, $100 \mu \mathrm{L}$ aliquots of the solution in each well were transferred to a new plate and the absorbance then measured at $570 \mathrm{~nm}$ using a microplate reader. (Elx-800-UV, Bio-Tek Instruments ${ }^{\circledR}$ )

\section{Cell proliferation}

Cell proliferation was examined using a Quant-i $\mathrm{T}^{\mathrm{TM}}$ PicoGreen assay kit (Molecular Probes), according to the manufacturer's instructions. The normal procedure described in the kit protocol and the accompanying DNA standards (up to $1,000 \mathrm{ng} / \mathrm{mL}$ ) were used. Cells $\left(1 \times 10^{4}\right.$ cells $/ \mathrm{mL}$ in $200 \mu \mathrm{L}$ of DMEM supplemented with $10 \% \mathrm{FBS})$ were seeded in wells containing the scaffolds and incubated for $1,7,14$ and 21 days. At the end of each period, the medium was aspirated from the wells and the scaffolds were washed five times with $200 \mu \mathrm{L}$ of PBS. Subsequently, $200 \mu \mathrm{L}$ of Tris-EDTA (TE) buffer was added to each sample, frozen at $-80{ }^{\circ} \mathrm{C}$ overnight and then thawed at $37^{\circ} \mathrm{C}$. The seeded scaffolds were sonicated for $5 \mathrm{~min}$ each and samples then aliquoted in duplicate $(100 \mu \mathrm{L})$ into a 96 -well flat bottomed plate. PicoGreen reagent $(100 \mu \mathrm{L})$ was added to the wells containing standard or sample and the plate then read at excitation/emission wavelengths of $485 / 538 \mathrm{~nm}$ in fluorometer (LS-55, PerkinElmer ${ }^{\circledR}$ ). The resulting fluorescence was compared with a standard curve of DNA and the cell number was calculated by assuming $7.7 \mathrm{pg}$ of DNA/cell22,23.

\section{Cell morphology}

Cell morphology was assessed by scanning electron microscopy (SEM) after $24 \mathrm{~h}, 7$ and 14 days of culture. The samples were rinsed with phosphate-buffered saline (PBS) and fixed for $1 \mathrm{~h}$ at room temperature in a solution prepared by dissolving $2.5 \%$ paraformaldehyde, $2.5 \%$ glutaraldehyde, $0.03 \%$ picric acid and 1\% tannic acid in PBS, and was followed by two rinses in PBS. After immersion in $1 \%(\mathrm{v} / \mathrm{v})$ osmium tetroxide $\left(\mathrm{OsO}_{4}\right)$ solution for $1 \mathrm{~h}$, the samples were rinsed twice in deionized water and dehydrated in a graded ethanol series $(70 \%, 80 \%, 95 \%$ and $100 \%)$ for $15 \mathrm{~min}$ each. The fixed samples were freeze-dried, sputter-coated with gold and examined with a JEOL JXA-840A microscope.

\section{Statistical analysis}

The data for cell viability and cell proliferation were expressed as the mean \pm standard deviation (SD) for $n=5$ experiments or determinations. Statistical comparisons were done using analysis of variance (ANOVA) followed by the Tukey test with $(\mathrm{p}<0.05)$ indicating significance. All data analyses were done using BioEstat ${ }^{\circledR} 5.0$ statistical software.

\section{In vivo experiments Animals and surgery}

Eight Wistar rats (250-300 g) 20 weeks old were anesthetized with a combination of ketamine and xylazine (50 $\mathrm{mg} / \mathrm{kg}$ and $10 \mathrm{mg} / \mathrm{kg}$, i.p., respectively). The dorsal part of the cranium was shaved, aseptically prepared for surgery and a sagittal incision of $\sim 30 \mathrm{~mm}$ was opened over the scalp. The periosteum was removed and a full-thickness bone defect ( 5 $\mathrm{mm}$ in diameter) was trephined in the center of each parietal bone using a trephine bur (Figure 1) adapted to a low-speed motor (LB100, Beltec ${ }^{\circledR}$ ). The right bone defect was filled with pre-seeded scaffolds ( $1 \mathrm{~mm}$ thick) while the other was left empty (control). The incision was sutured using nylon monofilament 4.0. All procedures involving animals were approved by the Committee for Ethics in Animal Use of the Universidade do Vale do Paraíba (UNIVAP), São José dos Campos, SP, Brazil (protocol no. A01/CEP/2009 and A038/CEP/2009). 


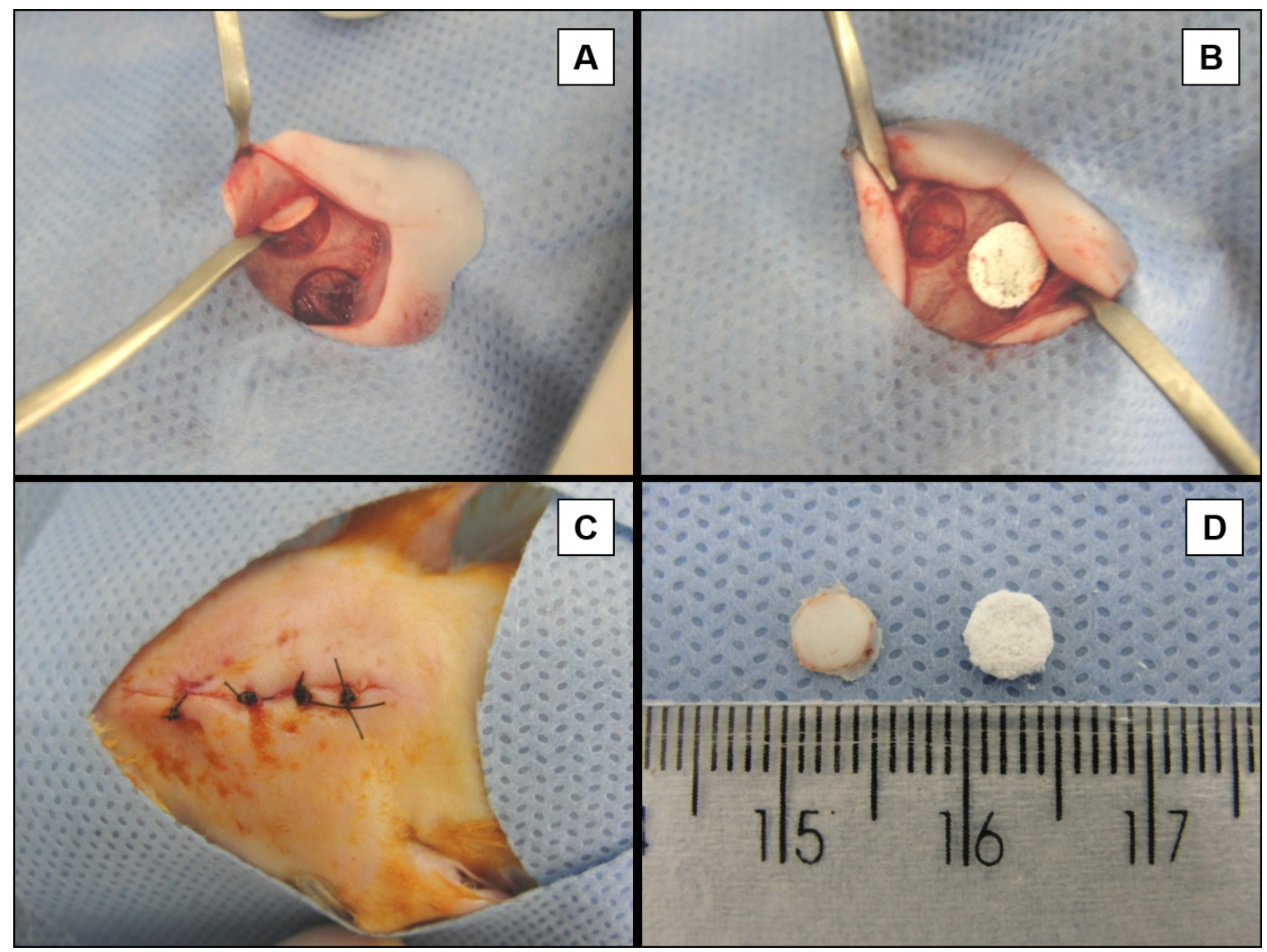

Figure 1. (A) Bilateral $5 \mathrm{~mm}$ critical-size calvarial defects created using a surgical trephine drill. (B) Implant of the PLDLA construct into the defect on the right; the left defect was empty and served as the control. (C) Suture. (D) Comparison of native calvarial and polymeric scaffolds.

\section{Tissue processing}

Four animals were euthanized 8 and 12 weeks postoperatively by an overdose of halothane after which the soft tissues were removed and the calvaria fixed in $4 \%$ formaldehyde for $24 \mathrm{~h}$ followed by decalcification in $4.13 \%$ EDTA for three weeks. Following complete decalcification, samples were dehydrated and embedded in paraffin. Serial sections $3 \mathrm{~mm}$ thick were cut on a microtome (Leica RM2245 ${ }^{\circledR}$ ) in a longitudinal direction starting at the center of the original surgical defect. The samples were then stained with hematoxylin-eosin (H\&E) and examined by light microscopy using a microscope (Eclipse E800 microscope, Nikon ${ }^{\circledR}$ ).

\section{RESULTS AND DISCUSSION}

\section{Cell compatibility assay}

Prior to implantation of the PLDLA scaffolds in vivo, an in vitro preliminary study of their cytocompatibility was performed by culturing osteoblast-like cells on the scaffolds. The viability of cells cultured on PLDLA scaffolds after $2 \mathrm{~h}$ and $24 \mathrm{~h}$ was determined by the colorimetric MTT assay. Figure 2 shows the viability (absorbance) of cells cultured in TCPS wells (positive control), in wells containing PLDLA scaffolds and in TCPS containing a toxic substance $(10 \%$ phenol; negative control). The PLDLA scaffolds did not adversely affect cell viability compared to positive control since the amount of viable cells adhered to substrate) was similar in both groups; in contrast, osteoblasts viability was markedly affected on negative control when compared to positive control and PLDLA scaffolds $(\mathrm{p}<0.01)$.

Only after adhered, cells are able to proliferate, spread, migrate and produce new extracellular matrix ${ }^{24}$. Figure 3 shows the growth curve of cells cultured on PLDLA scaffolds as assessed by DNA quantification using Picogreen reagent. The number of cells was calculated assuming a DNA concentration of $7.7 \mathrm{pg} / \mathrm{cell}^{22,23}$. As can be seen, scaffolds not only led cell adhesion on scaffolds surface as well as stimulated a progressive increase in osteoblast proliferation along the first 14 days of culture $(\mathrm{p}<0.05)$.

No control groups were used in this assay because of the lack of an adequate experimental model capable of accurately representing the biological microenvironment of the three-dimensional scaffold structure ${ }^{24}$. In addition, it is well known that the wells of tissue culture plates, which are often used as controls for in vitro assays, are incapable of supporting cell proliferation at initial cell concentrations $>10^{4}$ cells $/ \mathrm{mL}$ for long periods of time in bidimensional systems $^{25}$.

In the present study, PLDLA scaffolds obtained by the porogen-leaching method were used to assess the 


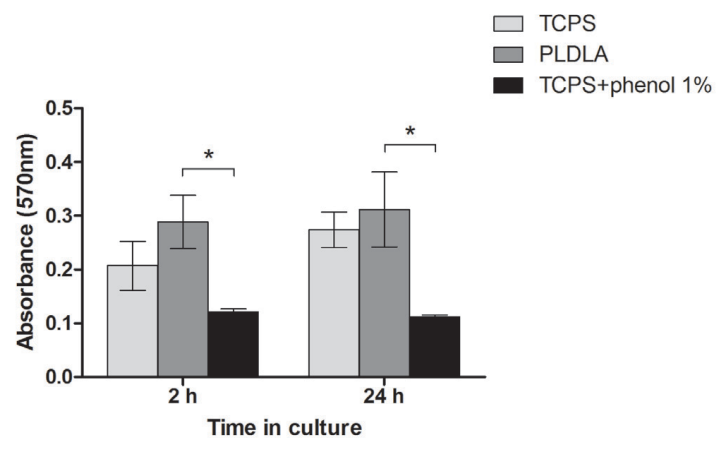

Figure 2. Viability of osteoblastic-like cells cultured on PLDLA scaffolds for $2 \mathrm{~h}$ and $24 \mathrm{~h}$. Cell viability was assessed by the MTT assay and expressed as the absorbance of the purple formazan product indicative of viable cells . The positive control consisted of cells grown in TCPS wells without any additions, while the negative control consisted of cells exposed to $10 \%$ phenol. The columns are the mean \pm SD of five independent experiments. ${ }^{*} \mathrm{p}<0.01$ compared to the control and PLDLA groups.

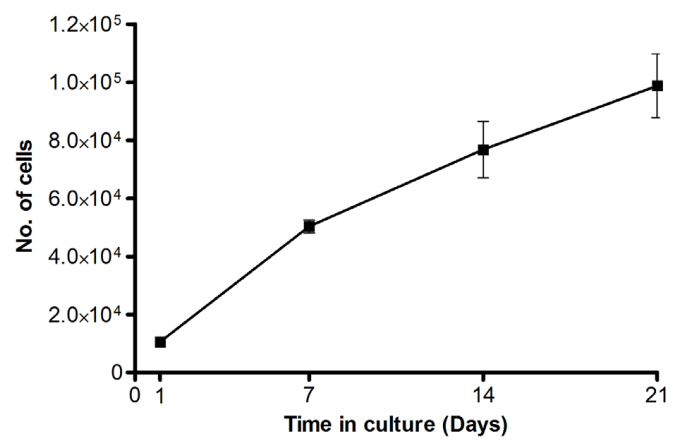

Figure 3.Proliferation of osteoblast-like cells grown on PLDLA scaffolds for 21 days. The points represent the mean \pm SD of five independent experiments. cytocompatibilty and biocompatibility of scaffolds with osteoblast-like cells because of the ease with which these scaffolds can be manufactured and the possibility of controlling pore size and structure ${ }^{26}$. Figure 4A shows SEM micrograph of the surface of a PLDLA scaffold.

The surface was characterized by homogeneously distributed irregular pores, with a range of pore sizes and surface topography that provided good interaction between cells and PLDLA scaffold surface during the first $24 \mathrm{~h}$ of culture (Figure 4B). Osteoblast-like cells adhered on scaffolds and had a flattened, elongated or polygonal morphology with cytoplasmic projections extending away from the central body to the top of adjacent wall pores.

From day 7 to 14 of culture, several non-specific areas of the material surface were covered by a cellular layer as a result of osteoblast proliferation and migration (Figure 4 C,D). These findings confirmed the cytocompatibility of PLDLA scaffolds with osteoblast-like cells and their ability to support suitable cell growth that could be useful in bone tissue engineering applications.

\section{Histological analysis of PLDLA scaffolds implanted in rats}

To evaluate the in vivo biocompatibility and influence of the PLDLA scaffolds on bone healing, cell-seeded PLDLA scaffolds (constructs) were implanted in bilateral critical-size calvarial defects in Wistar rats and assessed histologically at 8 and 12 weeks after implantation. All rats recovered well during the post-surgical procedure, with no clinical signs of acute infection in the area of the defect and no systemic complications, which were only assessed macroscopically.

Figure 5 shows histological images of PLDLA constructs 8 weeks after implantation. In the control group (empty defect), the center of the defect area was filled with thin fibrous

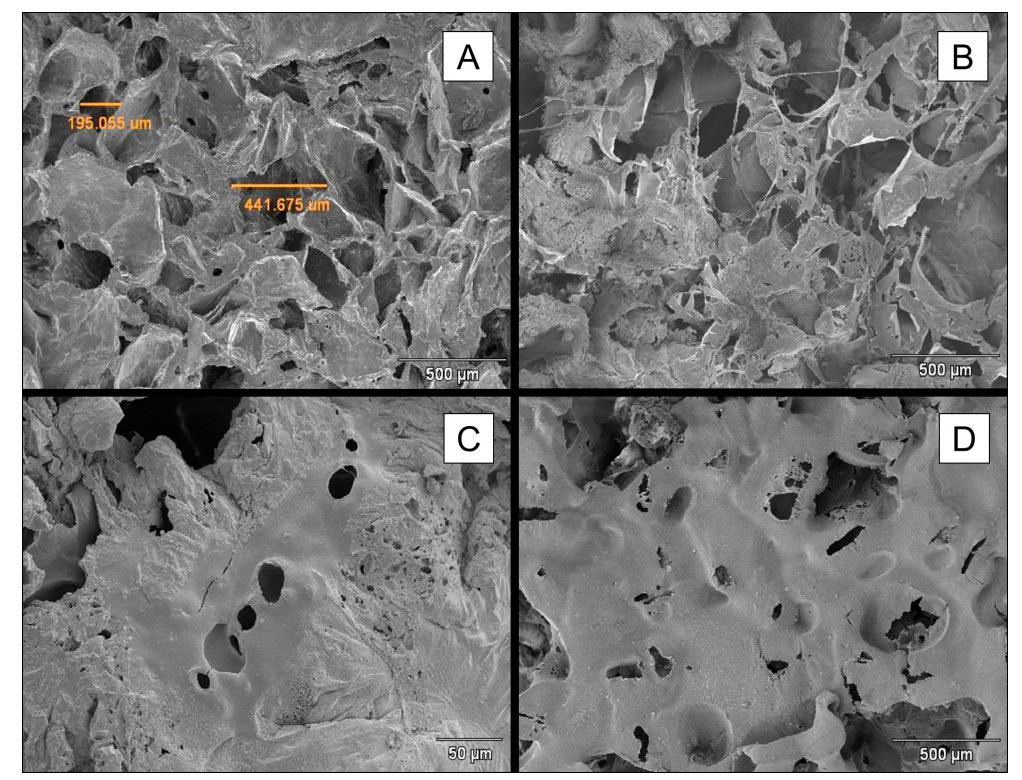

Figure 4. (A) Scanning electron micrograph of the surface of a PLDLA scaffold. (B) Osteoblastic-like cells cultured on a PLDLA scaffold for 24 h. (C) Beginning of cell colonization in non-specific areas of the scaffold surface after 7 days in culture. (D) Formation of net-like tissue covering the surface pores of a PLDLA scaffold after 14 days in culture. 


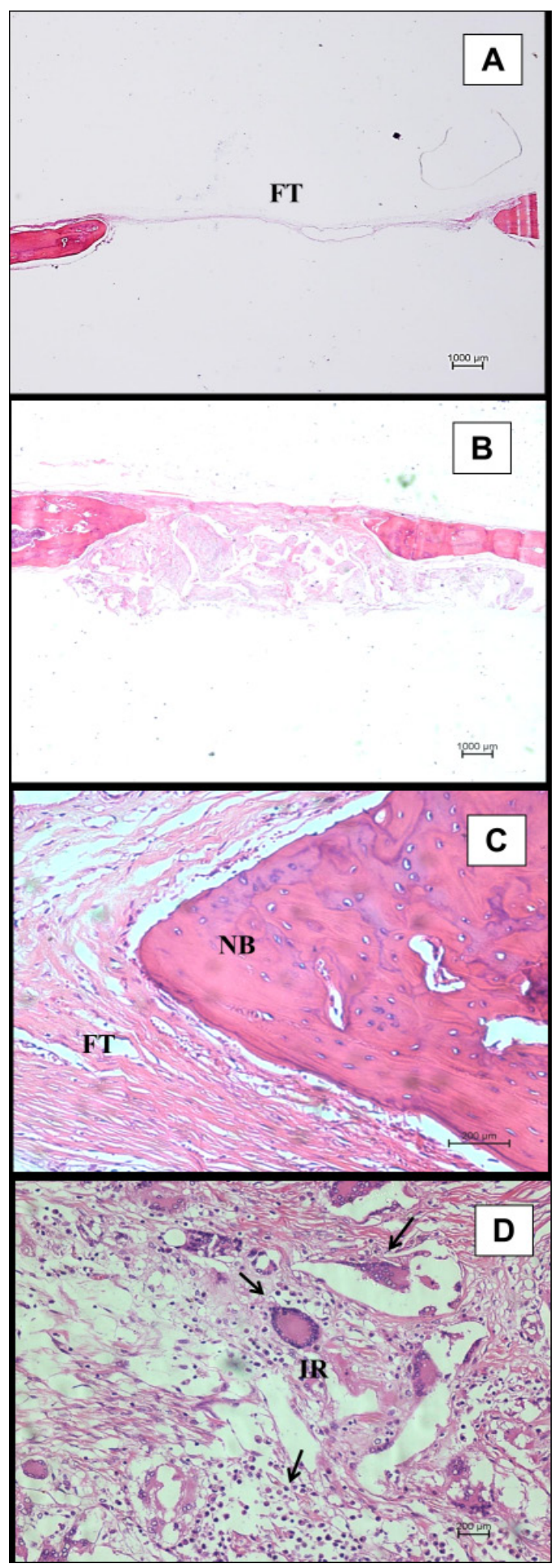

Figure 5. Histological alterations eight weeks after scaffold implantation. Light microscopy (HE) of the critical size calvarial defect at the control (empty defect) and scaffold-treated (PLDLA construct) sites. (A) The control site showed the presence of thin fibrous tissue (FT). (B) Panoramic image of the implanted PLDLA construct. (C) Fibrous tissue (FT) formed at the interface between new bone (NB) and the PLDLA scaffold implantat the defect margin. (D) Severe inflammatory reaction (IR) showing lymphocytes, macrophages and foreign-body giant cells (arrows) inside the implanted PLDLA scaffold. connective tissue while there was minimal bone formation at the borders of the defect (Figure 5A).

There was greater bone formation surround the margins of defect in the implants of the PLDLA constructs compared to the control group (Figure 5B), indicating that the 3D structure of the scaffolds was able to stimulate tissue ingrowth by providing mechanical assistance until the newly formed bone tissue assumed its biological functions. There was also an obvious belt of connective tissue fibers surrounding the space occupied by the material and the margins of the defect (Figure 5C).

Implantable biomaterials are recognized as foreign by the body and immediately after implantation, induce an initial host response to eliminate this foreign body. The magnitude and duration of the inflammatory process has a major influence on the stability and biocompatibility of the device ${ }^{27}$.

Figure 5D shows that a severe inflammatory response involving the infiltration of leukocytes, macrophages and giant cells was observed with all PLDLA implants. These reactions occurred primarily in the center of the defects, around the particle-polymer interface within the scaffold. The inflammatory response observed in the implants was not considered to be indicative of a toxic effect of the PLDLA constructs but was most likely related to the rapid degradation of the PLDLA polymer at this stage, which can result in a high concentration of polymer fragments and local acidification of the implanted area ${ }^{8,11,28,29}$.

The previous in vitro analysis of PLDLA degradation showed that material degradation starts after 8 weeks and is less pronounced after 16 weeks. It means that fewer polymer fragments and acidic degradation products are generated at the site of implant in the latter interval ${ }^{1,12}$. Besides, we have reported a similar PLDLA degradation rate and decrease in the inflammatory response along the time in the simulated internal fixation of PLDLA devices such as plates and screws in rabbit tibial implants ${ }^{30}$.

Figure 6 shows the histological appearance of PLDLA constructs after 12 weeks of implantation.

Panel A of this figure shows the presence of fibrous connective tissue in the control defect, although in two of four animals the control defect was also filled with a thin, uniform layer of newly formed bone (data not shown), indicating that the $5 \mathrm{~mm}$ critical size defect used was not optimal for this study.

Calvarial critical size bone defects have been used in various studies to investigate the effectiveness of bone regenerative agents such as growth factors, biomaterials, cell or tissue implants, or any combination of these in repairing defective bone. However, the optimal critical size for bone calvarial defects within a given species remains controversial ${ }^{11,32}$.

In relation to the PLDLA scaffolds used in this work (Figure 6B), we observed active new bone formation in the central area of the implants that showed continuity with bone tissue growing inwards from the defect margins. In addition, a considerable amount of new thin bone trabeculae was observed surrounding the material implanted in the defect. However, in only one case the defect was completely filled with newly formed bone.

The inflammatory reaction within the implant decreased over time when compared with that seen after 8 weeks of implantation. The fibrous connective tissue became more disordered at the margins of control and implanted defects 


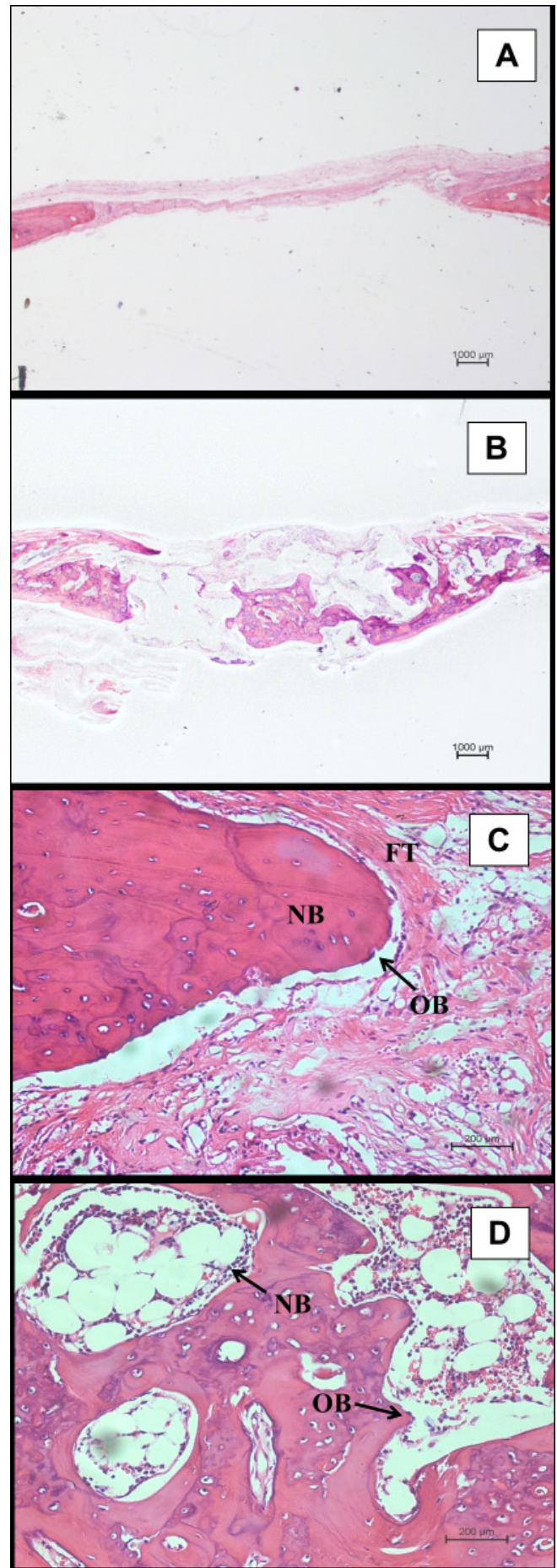

Figure 6. Histological alterations 12 weeks after scaffold implantation. Light microscopy (HE) of the critical size calvarial defect at control (empty defect) and scaffold-treated (PLDLA construct) implants. (A) Control site filled with thin fibrous connective tissue. (B) Bone formation in the center of the implant. (C) Presence of active osteoblasts $(\mathrm{OB})$ around newly formed bone at the margin of a defect implanted with a PLDLA scaffold. Note the presence of fibrous tissue (FT) at the interface between new bone (NB) and space of implanted PLDLA. (D) New bone (NB) in a defect implanted with a PLDLA scaffold. Note the inflammatory reaction (arrow) and active osteoblasts $(\mathrm{OB})$ surrounding the remaining polymeric fragments areas.
(Figure 6C) and in the central area of the implant. A persistent tissue response was observed inside and around the remaining polymer fragments in the central area of newly formed bone (Figure 6D), thus confirming that the severe inflammatory response seen after 8 weeks was caused essentially by factors related to polymer degradation.

Careful histological analysis showed that the areas of newly formed bone gradually joined up to close the defect. During this process, the rate of PLDLA scaffold degradation was similar to that of bone formation since no signs of impaired bone growth, such as necrosis and fibrous capsule formation around the implanted material, were observed. These results indicated a good interaction at the interface between newly bone formed and the implanted PLDLA construct ${ }^{33}$.

Although the histological analysis has revealed that the PLDLA constructs were biocompatible with bone tissue and were not cytotoxic during tissue repair, we assumed that some factors related to the porogen-leaching method used to manufacture the scaffolds may have affected the interactions between the PLDLA constructs and native tissue, thereby preventing better PLDLA scaffold-cell interaction and bone formation. Such factors include the lack of control of pore interconnectivity and pore size within the scaffold and the difficulty in obtaining scaffolds $\sim 1 \mathrm{~mm}$ thick (a thickness close to that of native calvarial). These factors may have influenced the scaffold permeability and hindered fluid diffusion through the polymeric network. This in turn would affect polymer degradation and hinder the transport of nutrients to the implanted area and to cells pre-seeded on scaffolds ${ }^{34-36}$.

Within the limits of this study, the contribution and influence of transplanted osteoblast-like cells in bone replacement could not be assessed in terms of enhanced bone formation. However, histological results provided evidences on the benefits of using PLDLA scaffolds as synthetic temporary matrix in bone repair process, supporting a better growth and distribution of bone formation within the implanted area that was not seen in the control group. The latter generally showed only a uniform, thin bone layer covering the defect.

\section{CONCLUSIONS}

The results of this study have shown the potential usefulness of PLDLA copolymer as a scaffold for bone replacement procedures. The porogen-leached scaffolds were biocompatible with bone tissue and supported and stimulated osteoblast-like cell growth and migration, and still indicate the maintenance of cell morphology. The use of PLDLA cell-scaffold constructs in vivo showed that the material was mechanically stable, with a degradation rate similar to that of bone formation. The 3D structure of the constructs facilitated tissue growth into the implanted area and stimulated better distribution of the starting points of bone formation. More detailed studies of PLDLA polymer as a scaffold for bone regeneration are needed to confirm its usefulness for bone tissue engineering.

\section{Acknowledgements}

This work was supported by Fundação de Amparo à Pesquisa do Estado de São Paulo (FAPESP, grant no. 2012/12081-2) and the National Institute of Science and Technology in Biofabrication (INCT-Biofabris). 


\section{REFERENCES}

1. Bitar KN, Zakhem E. Design strategies of biodegradable scaffolds for tissue regeneration. Biomedical Engineering and Computational Biology. 2013;6:13-20. doi: 10.4137/BECB. S10961

2. Sharmas S, Srivastava D, Grover S, Sharma V. Biomaterials in tooth tissue engineering: a review. Journal of clinical and diagnostic research: JCDR. 2014;8(1):309-315. doi: 10.7860/ JCDR/2014/7609.3937

3. Fröhlich M, Grayson WL, Wan LQ, Marolt D, Drobnic M, Vujnak-Novakovi G. Tissue engineered bone grafts: biological requirements, tissue culture and clinical relevance. Current Stem Cell Research \& Therapy. 2008;3(4):254-264.

4. Shin, H. Fabrication methods of an engineered microenvironment for a nalysis of cell-biomaterial interactions. Biomaterials. 2007;28 (2):126-133. DOI: 10.1016/j.biomaterials.2006.08.007

5. Seyednejad H. Functional aliphatic polyesters for biomedical and pharmaceutical applications. Journal of Controlled release. 2011; 152(1) :168-176. doi: 10.1016/j.jconrel.2010.12.016

6. Yu NY, Schindeler A, Little G, Ruys AJ. Biodegradable poly ( $\alpha$-hydroxy acid) polymer scaffolds for bone tissue engineering. Journal of Biomedical Materials Research Part B: Applied Biomaterials. 2010;93(1):285-295. DOI: 10.1002/jbm.b.31588

7. Motta AC, Duek EA. Synthesis, characterization, and" in vitro" degradation of poly (L-lactic acid-co-glycolic acid), PLGA. Matéria (Rio de Janeiro). 2006; 11 (3):340-350. http://dx.doi. org/10.1590/S1517-70762006000300024

8. Motta AC, Duek EA. Síntese e caracterização do copolímero poli (L-co-D, L Ácido Láctico). Polimeros: Ciencia e Tecnologia. 2007;17 (2):123-129.

9. Esposito AR, Moda M, Cattani SM, Santana M, Barbieri JÁ, Munhoz MM, et al. PLDLA/PCL-T Scaffold for Meniscus Tissue Engineering. BioResearch Open Access. 2013;2(2):138-147.

10. Mistura DV, Messias AD, Duek EA, Duarte MA. Development, characterization, and cellular adhesion of poly (1-Lactic Acid)/ Poly (caprolactone triol) membranes for potential application in bone tissue regeneration. Artificial Organs. 2013;37(11): 978-984.

11. Ciambelli GS, Perez MO, Siqueira GV, Candella MA, Motta AC, Duarte MA, et al. Characterization of poly (L-co-D, L Lactic Acid) and a study of polymer-tissue interaction in subcutaneous implants in wistar rats. Materials Research. 2013;16(1): 28-37. http://dx.doi.org/10.1590/S151 6-14392012005000146

12. Pezzin AP, Cardoso TP, Rincón MC, Zavaglia CA, Duek EA. Bioreabsorbable polymer scaffold as temporary meniscal prosthesis. Artificial Organs. 2003;27(5): 428-431. DOI: 10.1046/j.15251594.2003.07251.x

13. Sakata MM, Alberto-Rincon MC, Duek EA. Estudo da interação polímero/cartilagem/osso utilizando poli (Ácido Lático-co-Ácido Glicólico) e poli (p-Dioxanona) em condilo femural de coelhos. Polímeros: Ciência e Tecnologia. 2004;14(3):176-180.

14. Pinto MR, Mariano EC, Alberto-Rincon MC, Duek EA. Análise histológica da Blenda PLLA/PCL como prótese de menisco. Revista Matéria [Internet]. 2009 [citado 2015 Jul 27];14(4):11621171. Disponível em: http://www.materia.coppe.ufrj.br/sarra/ artigos/artigo11112

15. Minata MK, Motta AC, Brbo ML, Rincon MC, Duek EA. Biocompatibility study of poly (L-acid-lactic)/polycaprolactone triol blend. Polimeros. 2013;23(2): 242-247.http://dx.doi. org/10.4322/polimeros.2013.074

16. Baraúna GS, Pierucci A, Oliveria A, Duarte MA, Duek EA. Estudo da degradação" in vivo" de poli (L-co-D, L-ácido láctico) aplicado como prótese para regeneração nervosa periférica. Revista Matéria [Internet]. 2007 [citado 2015 Jun 21];12(2):298-306. Disponível em: http://www.materia.coppe. ufrj.br/sarra/artigos/artigo10851

17. Baraúna G, Coraça-Huber DC, Duek EA. In vitro degradation of Poly-L-co-D, L-lactic acid membranes. Materials Research. 2013;16(1):221-226. http://dx.doi.org/10.1590/S151614392012005000154

18. Motta AC, Duek EA. Estudo inicial da degradação "in vitro" de poli (L-co-DL ácido lático) sintetizado em laboratório. Matéria (Rio de Janeiro). 2008;13(3): 429-438.http://dx.doi. org/10.1590/S1517-707620080003

19. Murphy CM, Matsiko A, Haugh M, Gleeson J, O'Brien FJ. Mesenchymal stem cell fate is regulated by the composition and mechanical properties of collagen-glycosaminoglycan scaffolds. Journal of the Mechanical Behavior of Biomedical Materials. 2012;7:53-62. DOI: 10.1016/j.jmbbm.2011.11.009

20. Lucchesi C, Barbanti SH, Joazeiro PP, Duek EA. Cell culture on PCL/PLGA blends. Journal of Applied Polymer Science. 2010;115 (5):2609-2615. DOI: 10.1002/app.29919

21. Más BA, Cattani SM, Rangel RC, Ribeiro GA, Cruz NC, Leite FL, et al. Surface characterization and osteoblast-like Cells culture on collagen modified PLDLA scaffolds. Materials Research. 2014;17(6):1523-1534. http://dx.doi.org/10.1590/15161439.269414

22. Blumenstein R, Dias M, Russo IH, Tahin Q, Russo J. DNA content and cell number determination in microdissected samples of breast carcinoma in situ. International Journal of Oncology. 2002; 21(2): 447-450.

23. Forsey RW, Chaudhuri JB. Validity of DNA analysis to determine cell numbers in tissue engineering scaffolds. Biotechnology Letters. 2009;31(6): 819-823. DOI 10.1007/s10529-009-9940-5

24. Santos AR, Ferreira BM, Duek EA, Dolder H, Wada RS, Wada ML. Differentiation pattern of vero cells cultured on poly (L-Lactic Acid)/Poly (Hydroxybutyrate-co-Hydroxyvalerate) blends. Artificial Organs. 2004;28(4) : 381-389. doi:10.1089/ ten.2005.11.182

25. Ng KW, Leong DT, Hutmacher DW. The challenge to measure cell proliferation in two and three dimensions. Tissue Engineering. 2005;11(1-2):182-191. doi:10.1089/ten.2005.11.182

26. Ke Y, Wang YJ, Ren L, Zhao QC, Huang W. Modified PHBV scaffolds by in situ UV polymerization: Structural characteristic, mechanical properties and bone mesenchymal stem cell compatibility. Acta Biomaterialia. 2010;6(4):1329-1336. DOI: 10.1016/j.actbio.2009.10.026

27. Nuss KM, Von Rechenberg B. Biocompatibility issues with modern implants in bone-a review for clinical orthopedics. The Open Orthopaedics Journal. 2008; 2:66-78. doi: 10.2174/1874325000802010066

28. Cai K, Yao K, Yang Z, Li X. Surface modification of threedimensional poly (d, 1-lactic acid) scaffolds with baicalin: a histological study. Acta Biomaterialia. 2007;3(4):597-605. DOI: 10.1016/j.actbio.2006.12.005

29. Montjovent MO, Mathieu L,Schmoekel H, Mark S, Bourban PE, Zambelli PY, et al. Repair of critical size defects in the rat cranium using ceramic-reinforced PLA scaffolds obtained by supercritical gas foaming. Journal of Biomedical Materials Research Part A, 2007;3(1):41-51.

30. Motta AC, Duek EA. Initial study of in vivo degradation of poly (L-lactic acid-co-D, Lácid láctic), PLDLA. Matéria (Rio de Janeiro). 2009;14(3):1070-1075. http://dx.doi.org/10.1590/ S1517-70762009000300018.

31. Cooper GM, Mooney MP, Gosain AK, Campbell PG, Losee JE, Huard J. Testing the "critical-size" in calvarial bone defects: 
revisiting the concept of a critical-sized defect (CSD). Plastic and Reconstructive Surgery. 2010;125(6):1685-1692. doi: 10.1097/PRS.0b013e3181cb63a3

32. Horner EA, Kirkham J, Wood D, Curran S, Smith M, Thomson $\mathrm{B}$, et al. Long bone defect models for tissue engineering applications: criteria for choice. Tissue Engineering Part B: Reviews. 2010;16(2): 263-271. DOI: 10.1089=ten.teb.2009.0224

33. Nagata MJ, Messora M, Pola N, Campos N, Vieira R, Esper $\mathrm{LA}$, et al. Influence of the ratio of particulate autogenous bone graft/platelet-rich plasma on bone healing in critical-size defects: A histologic and histometric study in rat calvaria. Journal of Orthopaedic Research. 2010;28(4): 468-473. DOI: 10.1002/ jor.21027
34. Ho ST, Hutmacher DW. A comparison of micro CT with other techniques used in the characterization of scaffolds. Biomaterials. 2006;27(8):1362-1376.

35. Subia B, Kundu J, Kundu SC. Biomaterial scaffold fabrication techniques for potential tissue engineering applications. In: Eberli D, editor. Tissue Engineering. and regenerative medicine [Internet] . 2010 . p. 142-157. [cited 2015 Nov 21]. Available from: http://www.intechopen.com/books/tissue-engineering/ biomaterial-scaffold-fabrication-techniques-for-potential-tissueengineering-applications

36. Suh SW, Shin JY, Kim J, Kim H, Beak CH, Kim DI, et al. Effect of different particles on cell proliferation in polymer scaffolds using a solvent-casting and particulate leaching technique. ASAIO Journal. 2002;48(5):460-464. 